\title{
INFEKSI CANDIDIASIS VULVOVAGINALIS PADA MUKOSA VAGINA YANG DISEBABKAN OLEH Candida sp.
}

\author{
St. Aisyah Sijid*, Zulkarnain, Sabilla Suryaning Amanda \\ Jurusan Biologi \\ Fakultas Sains dan Teknologi UIN Alauddin Makassar \\ Jl. Sultan Alauddin No. 63, Kabupaten Gowa, Sulawesi Selatan. 92113 \\ *Email: aisyah.sijid@uin-alauddin.ac.id
}

\begin{abstract}
Abstrak: Candidiasis vulvovaginalis merupakan salah satu infeksi yang diakibatkan adanya pertumbuhan dari jamur Candida sp. yang berlebihan. Infeksi ini menimbulkan gejala awal berupa keputihan abnormal dengan warna putih kekuningan, mengeluarkan bau yang menyengat, menimbulkan rasa gatal dan terbakar. $C$. glabrata, $C$. albicans dan $C$. parapsilosis merupakan spesies dari Candida sp. yang menimbulkan infeksi Candidiasis vulvovaginalis. Review ini menunjukkan infeksi Candidiasis vulvovaginalis yang disebabkan oleh jamur Candida sp. serta penyebab dari infeksi ini. Dari penelitian sebelumnya didapatkan hasil bahwa terdapat tiga spesies dari Candida sp. yang merupakan penyebab dari infeksi Candidiasis vulvovaginalis dan terdapat beberapa faktor yang merupakan penyebab dari infeksi ini. Akan tetapi pada penelitian ini hanya mendapatkan spesies dari Candida sp. yang merupakan penyebab penyakit ini sedangkan terdapat banyak flora normal lain dan juga jamur dari golongan yang terdapat pada vagina yang bisa saja menjadi penyebab dari infeksi ini. Sehingga dibutuhkan penelitian yang lebih lanjut dengan sampel keseluruhan dari vagina serta pendataan terhadap responden sehingga dapat diketahui faktor utama yang dapat menyebabkan infeksi ini terjadi sehingga didapatkan hasil yang lebih akurat.
\end{abstract}

Kata Kunci: Candidiasis vulvovaginalis, Candida sp., faktor penyebab infeksi

\section{PENDAHULUAN}

\footnotetext{
$C^{2}$ andidiasis vulvovaginalis merupakan salah satu infeksi yang disebabkan oleh Candida sp. yang menginfeksi vulva atau vagina. Pada dasarnya Candida sp. menginfeksi pada vagina (vaginitis) kemudian menyebar sampai pada vulva (vulvitis). Infeksi ini pada umumnya terjadi pada wanita usia subur dimana sekitar 70$75 \%$ wanita pada usia subur terinfeksi Candidiasisi vulvovaginalis dan bisa timbul untuk kedua kalinya (reinfeksi) kembali. C. glabrata, Candida albicans dan Candida parapsilosis merupakan penyebab dari Candidiasis vulvovaginalis (Harnindya \& Agusni, 2016). Candida sp. adalah salah satu jamur yang terdapat pada dinding vagina yang bersifat oportunis. Jamur ini bisa menjadi saprofit tanpa adanya suatu gejala yang ditimbulkan serta bisa menjadi patogen yang berdampak negatif bagi tubuh dan menyebabkan adanya suatu infeksi. Salah satu infeksi yang disebabkan jamur ini yaitu Candidiasis vulvovaginalis (Saydam, 2012).
} 
Gejala yang ditimbulkan oleh infeksi Candidiasis vulvovaginalis yaitu timbulnya keputihan berwarna putih kekuningan disertai rasa gatal, terbakar dan berbau. Hal ini dikarenakan adanya pertumbuhan dari spesies Candida sp. yang tidak terkendali. Pada dasarnya Candida sp. merupakan salah satu flora normal yang terdapat pada organ reproduksi wanita jika populasinya masih dalam ambang batas normal Candida sp. tidak dapat menyebabkan infeksi namun jika terjadi pertumbuhan yang tidak terkendali dan melampaui batas jumlah normal maka akan menyebabkan infeksi. Candida sp. dapat tumbuh tak terkendali pada vagina apabila vagina dalam kondisi kurang bersih, lembab dan tidak hygiene. Pemakaian antibiotik yang berlebihan dan pemakaian pembersih kewanitan yang tidak sesuai prosedur juga dapat menyebabkan pertumbuhan dari Candida sp. ini semakin meningkat (Tasik et al., 2016).

Infeksi Candidiasis vulvovaginalis merupakan salah satu permasalahan kesehatan dunia pada wanita yang menginfeksi $75 \%$ wanita setidaknya sekali dalam seumur hidup. Sekitar 138 juta wanita di seluruh dunia mengeluhkan infeksi ini karena mengalami infeksi ini untuk kedua kalinya. Hal ini disebabkan oleh kesalahan penangan klinis dan pemberian antibiotik yang berlebihan. Apabila terjadi infeksi yang berulang maka akan menyebabkan terjadinya komplikasi yang lebih kronis (Sherry et al., 2017).

Candidiasis vulvovaginalis dapat dikelompokkan menjadi dua kelompok yaitu komplikasi dan episodik. Pada episodik gejala yang ditimbulkan ringan sampai sedang, kemudian tidak menyebabkan demam dan tidak terjadi berulang atau reinfeksi. Sedangkan pada komplikasi terjadi infeksi yang berulang bahkan sampai empat kali dengan gejala yang parah dan komplikasi terhadap penyakit bawaan lainnya seperti diabetes dan HIV (Brocklebank, 2013).

Infeksi ini dapat menimbulkan infeksi yang berulang ulang dan terjadi pada wanita usia lanjut atau menopause. Infeksi ini disebabkan karena adanya perubahan fisiologis, anatomis dan histologis dari organ reproduksi dan saluran kemih. Salah satu penyebab infeksi ini pada usia lanjut dikarenakan menurunnya hormon estrogen karena salah satu fungsi dari hormon ini adalah berperan dalam pembentukan kolagen dan mukopolisakarida pada mukosa yang dapat membantu menjaga ketebalan dan kelembapan pada vagina. Karena kadar hormon estrogen ini menurun maka epitel vagina kehilangan elastisitasnya yang menyebabkan aliran darah berkurang serta meningkatkan $\mathrm{pH}$ vagina yang dapat menyebabkan flora normal berkembang biak dengan cepat sehingga pertumbuhannya tidak terkendali

Menurut Chunaifa et al. (2017) terdapat beberapa faktor penyebab dari infeksi Candidiasis vulvovaginalis yaitu sebagai berikut:

1. Usia dimana pada umumnya infeksi ini terjadi pertama kali pada usia masa subur namun dapat juga mengakibatkan infeksi berulang pada usia menopause

2. Kehamilan, merokok dan stres psikososial

3. Terapi dengan penggunaan antibiotik dan terapi imunosupresif

4. Perilaku seksual dan frekuensi hubungan seks

Mengenai angka terjadinya infeksi Candidiasis vulvovaginalis pada wanita maka sangat diperlukan adanya edukasi dini terhadap penyakit-penyakit IMS (infeksi menular seksual) salah satunya mengenai cara merawat dan membersihkan area kewanitaan dengan baik dan benar. Karena dengan menjaga kebersihan dan hygiene dari area vagina adalah solusi terbaik untuk mencegah berbagai macam infeksi baik yang disebabkan oleh jamur maupun bakteri (Nuraini et al., 2020). 


\section{KASUS INFEKSI CANDIDIASIS VULVOVAGINALIS}

Berdasarkan penelitian yang telah dilakukan oleh Sherry et al. (2017) didapatkan hasil bahwa dari 300 pasien yang terinfeksi Candidiasis vulvovaginalis yang dilakukan dengan pemeriksaan hasil swab vagina terdapat 212 yang terinfeksi karena $C$. albicans, 47 yang terinfeksi karena $C$. glabrata, 17 yang terinfeksi karena $C$. dubliniensis, 10 yang terinfeksi karena $C$. parapsilosis dan sisanya terinfeksi spesies Candida sp. Lainnya (Gambar 1).

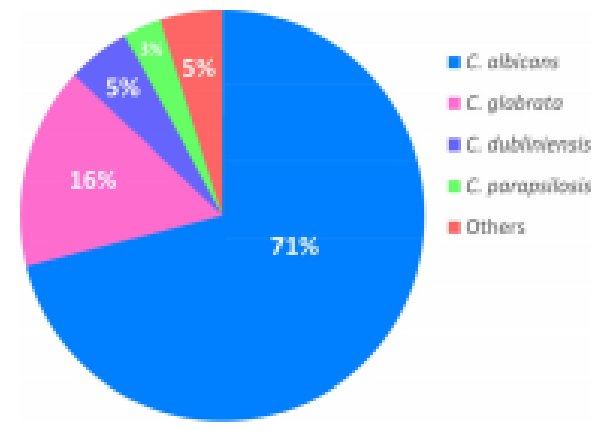

Gambar 1. Distribusi dari isolasi organisme hasil swab 300 pasien (Sherry et al., 2017)

Berdasarkan penelitian yang telah dilakukan oleh Puspitorini et al. (2018) mengenai faktor resiko KVV (Kandidiasis Vulvovaginalis) didapatkan hasil bahwa pada usia 15-24 tahun terdapat 25 pasien yang terinfeksi KVV dengan keluhan dalam jangka waktu terlama adalah 1-9 bulan dengan riwayat penyakit bawaan lainnya, pemakaian douching vagina serta terjadi penurunan imun. Dari hasil pemeriksaan laboratorium dengan pemeriksaan sediaan basah didapatkan terdapat blastospora yang positif. Dan pen yebab KVV setelah dikultur pada media didapatkan hasil bahwa yang tumbuh $100 \%$ adalah spesies dari Candida sp.

Berdasarkan penelitian yang telah dilakukan Chunaifa et al. (2017) mengenai stres psikososial dan kejadian KVV pada wanita pekerja seks di Banyumas didapatkan hasil bahwa faktor utama yang menyebabkan infeksi Candidiasis vulvovaginalis pada wanita pekerja seks di Banyumas adalah perilaku seks yang berlebihan juga seks secara oral dan aktivitas merokok yang berlebihan yaitu sekitar 10 batang/hari. Berdasarkan penelitian yang telah dilakukan oleh Harnindya \& Agusni (2016) mengenai diagnosis dan penatalaksanaan KKV didapatkan hasil bahwa dari hasil lab yang telah dilakukan, terdapat 217 pasien dari 220 pasien yang positif dengan pemeriksaan duh tubuh vagina. Penelitian ini dilakukan dengan menggunakan metode restrospektif dan pengambilan data rekam medik dari pasien yang teindikasi mengidap infeksi Candidiasis vulvovaginalis.

\section{KESIMPULAN}

Candidiasis vulvovaginalis merupakan salah satu infeksi yang disebabkan oleh jamur spesies Candida sp. yang menginfeksi vagina terutama pada mukosa vagina. $C$. albicans, C. glabrata, C. dubliniensis, C. parapsilosis merupakan spesies jamur yang menyebabkan infeksi Candidiasis vulvovaginalis ini terjadi. Terdapat beberapa faktor yang dapat menyebabkan infeksi ini yaitu usia, perilaku seks dan juga aktivitas merokok yang berlebihan. 


\section{DAFTAR PUSTAKA}

Brocklebank, A. Vulvovaginal candidiasis. (2013). InnovAiT, 10(6), 643-651. Doi:10.1136/sti.2006.023168.

Chunaifa, L., Rahayujati, B., \& Prabandari, Y. (2017) Stres psikososial dan kejadian kandidiasis vulvovaginalis pada wanita pekerja seks di Banyumas. Berita Kedokteran Masyarakat, 33(7), 331334. Doi. 10.22146/bkm.18029.

Harnindya, D \& I. Agusni. (2016) Retrospective study: Diagnosis and management of vulvovaginalis candidiasis. Berkala Ilmu Kesehatan Kulit dan Kelamin, 28(1), 42-48.

Nuraini, S., Y. Herliani., N. Mulyani., \& A. Tajmiati (2018) Mini review: Prevalensi vulvovaginosis di Indonesia." Jurnal Kesehatan Tasikmalaya, 1(3), 7-12.

Palacios, S., R. E. Nappib., N. Bruyniksd., M. Particcoe., \& N. Panay. (2018). The European Vulvovaginal Epidemiological Survey (EVES): Prevalence, symptoms and impact of vulvovaginal atrophy of menopause. Informa UK Limited, Trading as Taylor \& Francis Group, Climacteric, 21(3), 286291. Doi. 10.1080/13697137.2018.1446930.

Puspitorini, D., Astari, L., Widya, L., Anggraeni, S., Ervianti, E., Rosita, C., \& Suyoso, S. (2018). Faktor risiko kandidiasis vulvovaginalis ( KVV ). Berkala Ilmu Kesehatan Kulit dan Kelamin-Periodical of Dermatology and Venereology, 30, 193-200.

Sherry, L., R. Kean, E. McKloud., L. E. O'Donnell., R. Metcalfe., B. L Jones., \& G. Ramage. (2017). Biofilms formed by isolates from patients are heterogeneous and insensitive to fluconazole. Antimicrob Agents Chemother, 61(9), 1-4.

Tasik, N. L., G. M. Kapantow., \& R. T. Kandou. (2013). Profil kandidiasis vulvovaginalis di Poliklinik Kulit dan Kelamin RSUP Prof. Dr. R. D. Kandou Manado periode Januari-Desember. E-CliniC, 4(1), 201-214. Doi. 10.35790/ecl.4.1.2016.10957.

Saydam, S. (2012). Waspadai penyakit reproduksi anda. Bandung: Pustaka Reka. 